\title{
Antepartum Uterine Rupture
}

National Cancer Institute

\section{Source}

National Cancer Institute. Antepartum Uterine Rupture. NCI Thesaurus. Code C114370.

An acute symptomatic tearing of the uterine wall prior to the onset of labor. 